\title{
Timing and Severity of Pruning Effects on Cranberry Yield Components and Fruit Anthocyanin
}

\author{
Bernadine C. Strik ${ }^{1}$ \\ Department of Horticulture, 2042 Cordley Hall, Oregon State University, \\ Corvallis, OR 97331-2911
}

\author{
Arthur Poole ${ }^{2}$ \\ Coos County Extension, 290 North Central, Coquille, OR 97423
}

Additional index words. Vaccinium macrocarpon, fruit color

\begin{abstract}
Timing and severity of pruning in a 30-year-old commercial 'McFarlin' cranberry (Vaccinium macrocarpon Ait.) bed were studied. Treatments in 1989 and 1990 consisted of early or late pruning and heavy, moderate, light, or no pruning. Yield component data were collected in Fall 1989 and 1990, just before harvest. Time of pruning did not affect yield components. In 1989, the unpruned and lightly pruned vines had a higher total plant fresh weight, fewer berries, higher berry yield, longer and more fruiting uprights, and fewer nonfruiting uprights (U,) compared with moderately or heavily pruned vines. Average length of $U_{N}$ and anthocyanin content of berries in 1989 were not influenced by pruning. In 1990, the effects of pruning severity were similar to 1989. In 1990, unpruned vines had a lower percent fruit set and berries contained less anthocyanin than pruned vines. Annual pruning with conventional systems in use decreases yield.
\end{abstract}

Mature cranberry beds tend to produce excessive vegetative growth, characterized by long runners and old, long, upright shoots. Reductions in yield may result, probably by limited light interception and decreased flower bud formation (Chambers, 1918; Eck, 1990). Excessive vine growth also creates a microclimate conducive to fruit rot development (Eck, 1990) and may limit fruit set. To maintain high yields, cranberries are periodically pruned to control excessive vegetative and runner growth. Pruning also enhances harvest efficiency by reducing interference of runners with harvest equipment. Chambers (1918) documented a $45 \%$ increase in yield the 2 nd year after a planting of vigorously growing 'Early Black' was pruned. Pruning severity is critical, however, as some fruiting uprights are also removed when runners are pruned (Chambers, 1918; Doehlert, 1955). Eck (1990) suggested a light annual pruning of vines would be the best approach to controlling excessive vegetative growth. However, little is understood about the immediate and long-term effects of pruning on components of yield.

\footnotetext{
Received for publication 1 Apr. 1991. The authors gratefully acknowledge the technical assistance of Dawna Jackson and-the support of the Oregon Cranberry Growers' Assn. The cost of publishing this paper was defrayed in part by the payment of page charges. Under postal regulations, this paper therefore must be hereby marked advertisement solely to indicate this fact.

'Assistant Professor.

${ }^{2}$ Horticultural Extension Agent.
}

Most cranberry beds in Oregon are flooded for fruit harvest (late September-October). Except for the few dry-harvested beds that also are pruned during harvest, pruning in Oregon is usually done from December-January. Late pruning may have an advantage over early pruning in years with injurious winter temperatures, as damaged wood would be removed during pruning.

Our objectives were to assess the effects of date of pruning and pruning severity on yield components and fruit anthocyanin content of cranberry.

A commercial 30-year-old 'McFarlin' cranberry bed was used. The experiment was set up as a split-plot design with three replicates. Time of pruning (early or late) was the main effect and pruning severity (heavy, moderate, light, or no pruning; Table 1) was the subplot effect. Plot size was $1.8 \times 6 \mathrm{~m}$. Treatments were repeated on each plot for two consecutive years. Pruning dates were 5 Dec. (1988 and 1989) and 9 Mar. (1989 and 1990) for the early and late treatments, respectively. A commercial pruner was used.

In Oct. 1989 and 1990, just before commercial harvest, yield component data were collected from three 3-dm ${ }^{2}$ samples, pooled, from each plot. Total sample plant fresh weight, total number of uprights $\left(\mathrm{U}_{\mathrm{T}}\right)$, number of nonfruiting uprights (U,), number of fruiting uprights (U,), average length of current season's growth of $U_{N}$ and $U_{F}$ (mean of 25 uprights randomly selected from sample), number of runners, number of $U_{F}$ with one through six fruit or flower pedicels per upright, number of nonmarketable berries, and number and weight of marketable berries were noted. Total anthocyanin content of fruit was determined by extracting a 100-g sample of fruit with $95 \%$ ethanol (Sapers and Hargrave, 1987). Average berry size, percent fruit set, and percent $U_{F}$ were calculated.

Timing of pruning did not influence yield components, suggesting that early pruning did not stimulate additional vegetative growth. Thus, data from the two pruning dates were pooled and analyzed as a randomized complete-block design. Analysis of variance and mean separations by a Waller test were done using the SAS statistical package (SAS Institute, Inc., 1987).

Unpruned and lightly pruned vines tended to produce more vegetative growth in 1989 than moderately or heavily pruned vines as expressed by a higher total sample plant fresh weight and $U_{F}$ length (Table 2). More differences in vegetative growth were apparent after two consecutive years of pruning treatments. In 1990, the unpruned and lightly pruned vines had a higher total sample plant fresh weight and $U_{N}$ length than moderately or heavily pruned vines. Also, unpruned vines had longer $U_{\mathrm{F}}$ than pruned vines. Unpruned vines tended to have more runners than those pruned, but none of the differences were significant (range 100-157 runner pieces).

Pruning severity treatment effects on reproductive growth were evident the first growing season after pruning, but differences among treatments were more pronounced after two consecutive seasons of pruning (Table 3). In 1989 and 1990, a negative relationship between yield and pruning severity was evident. Severely pruned vines yielded less than unpruned and lightly pruned vines (Table 3). Reduced yield resulted from fewer $\mathrm{U}_{\mathrm{F}}$, specifically $\mathrm{U}_{1}, \mathrm{U}_{2}$, and $\mathrm{U}_{3}$. and fewer marketable berries (Tables 2 and 3 ). Moderate and heavy pruning tended to remove $\mathrm{U}_{\mathrm{F}}$ along with runners, adversely affecting yield. Doehlert (1955) found even with careful removal of runner growth with hand shears that $7 \%$ of the uprights were removed. Chambers (1918) found a 10\% reduction in yield the year after pruning, possibly also due to $U_{\mathrm{F}}$ removal by pruning.

Pruning severity did not affect percent nonmarketable fruit ( $2 \%$ to $8 \%$ ) or berry weight $(0.7$ to $1.3 \mathrm{~g})$ in either year, or fruit set in 1989 (Table 3). Thus, canopy density did not influence fruit rot, as suggested by Eck (1990). Contrary to our results, Eaton and Kyte (1978) observed a negative relationship between berry weight and $\mathrm{U}_{\mathrm{T}}$ in

Table 1. Pruning severity treatments on 'McFarlin' cranberry in 1989 and 1990.

\begin{tabular}{lcc}
\hline \hline Pruning & $\begin{array}{c}\text { Canopy depth } \\
(\mathrm{cm})\end{array}$ & $\begin{array}{c}\text { Estimated wt of } \\
\text { prunings }\left(\mathrm{t} \cdot \mathrm{ha}^{-1}\right)\end{array}$ \\
\hline None & 22 & 0 \\
Light & 20 & 1.8 \\
Moderate & 18 & 2.6 \\
Heavy & 16 & 4.3 \\
\hline
\end{tabular}


Table 2. Effect of pruning severity on vegetative yield components of 'McFarlin' cranberry in 1989 and 1990.

\begin{tabular}{|c|c|c|c|c|c|c|c|c|c|c|c|}
\hline \multirow{2}{*}{ Pruning } & \multirow{2}{*}{$\begin{array}{l}\text { Total plant } \\
\mathrm{wt}^{\mathrm{z}}\left(\mathrm{g} / \mathrm{dm}^{2}\right)\end{array}$} & \multicolumn{2}{|c|}{$\begin{array}{l}\text { Upright lengthy } \\
\text { (mm) }\end{array}$} & \multicolumn{7}{|c|}{ No. uprights ${ }^{2, x}$} & \multirow{2}{*}{$\begin{array}{c}\mathrm{U}_{\mathrm{F}} / \mathrm{U}_{\mathrm{T}} \\
(\%)\end{array}$} \\
\hline & & $\mathrm{U}_{\mathrm{N}}$ & $\mathrm{U}_{\mathrm{F}}$ & $\mathbf{U}_{\mathrm{T}}$ & $\mathrm{U}_{\mathrm{N}}$ & $\mathrm{U}_{\mathrm{F}}$ & $\mathrm{U}_{1}$ & $\mathrm{U}_{2}$ & $\mathrm{U}_{3}$ & $\mathrm{U}_{4-6}$ & \\
\hline \multicolumn{12}{|l|}{1989} \\
\hline None & $69.9 \mathrm{a}^{\mathrm{w}}$ & 53 & $60 \mathrm{a}$ & 603 & $404 \mathrm{a}$ & 199 a & $58 \mathrm{a}$ & $70 \mathrm{a}$ & 48 & 25 & $35 \mathrm{a}$ \\
\hline Light & $65.6 \mathrm{a}$ & 51 & $54 \mathrm{ab}$ & 633 & $460 \mathrm{ab}$ & $173 \mathrm{ab}$ & $53 \mathrm{ab}$ & $63 \mathrm{ab}$. & 42 & 15 & $27 \mathrm{ab}$ \\
\hline Moderate & $44.1 \mathrm{~b}$ & 45 & $50 \mathrm{ab}$ & 687 & $556 \mathrm{bc}$ & $131 \mathrm{~b}$ & $41 \mathrm{~b}$ & $48 \mathrm{~b}$ & 30 & 13 & $19 \mathrm{bc}$ \\
\hline Heavy & $51.6 \mathrm{ab}$ & 46 & $47 \mathrm{~b}$ & 718 & $593 \mathrm{c}$ & $125 \mathrm{~b}$ & $36 \mathrm{~b}$ & $47 \mathrm{~b}$ & 31 & 11 & $18 \mathrm{c}$ \\
\hline $\begin{array}{l}\text { Significance } \\
1990\end{array}$ & $*$ & NS & $*$ & NS & $* *$ & 1990 & $*$ & $*$ & NS & NS & $* *$ \\
\hline None & $71.0 \mathrm{a}$ & $51 \mathrm{a}$ & $67 \mathrm{a}$ & 650 & 497 & $153 \mathrm{a}$ & $29 \mathrm{a}$ & $63 \mathrm{a}$ & $44 \mathrm{a}$ & 18 & $23 \mathrm{a}$ \\
\hline Light & $59.1 \mathrm{~b}$ & $49 \mathrm{a}$ & $53 \mathrm{~b}$ & 680 & 580 & $100 \mathrm{~b}$ & $20 \mathrm{ab}$ & $35 \mathrm{~b}$ & $32 \mathrm{ab}$ & 12 & $15 \mathrm{~b}$ \\
\hline Moderate & $51.6 \mathrm{c}$ & $42 \mathrm{~b}$ & $47 \mathrm{~b}$ & 647 & 575 & 72 bc & $18 \mathrm{~b}$ & $25 \mathrm{~b}$ & $20 \mathrm{bc}$ & 10 & $11 \mathrm{c}$ \\
\hline Heavy & $50.5 \mathrm{c}$ & $42 \mathrm{~b}$ & $45 \mathrm{~b}$ & 694 & 635 & $59 c$ & $15 \mathrm{~b}$ & $21 \mathrm{~b}$ & $17 \mathrm{c}$ & 6 & $9 c$ \\
\hline Significance $^{\mathrm{v}}$ & *** & ** & $* *$ & NS & NS & $* * *$ & $* *$ & $* * *$ & $* *$ & NS & ** \\
\hline
\end{tabular}

${ }^{2}$ Sample area of $930 \mathrm{~cm}^{2}$.

yAverage of 25 randomly selected uprights.

${ }^{x} U_{T}=$ total no. uprights; $U_{N}=$ No. nonfruiting uprights; $U_{1}-U_{6}=$ No. uprights with one to six pedicels, respectively; $U_{F}=$ no. fruiting uprights $=\Sigma$ $\left(\mathrm{U}_{1}+\mathrm{U}_{2}+\mathrm{U}_{3}+\mathrm{U}_{4}+\mathrm{U}_{5}+\mathrm{U}_{6}\right)$.

"Mean separation within seasons by the Waller test, $P<0.05$.

Ns, $*, * *, * * *$ Nonsignificant or significant at $P<0.05,0.01$, or 0.001 , respectively.

Table 3. Effect of pruning severity on fruiting characteristics of 'McFarlin' cranberry in 1989 and 1990.

\begin{tabular}{|c|c|c|c|c|c|}
\hline \multirow[b]{2}{*}{ Pruning } & \multirow{2}{*}{$\begin{array}{c}\text { Fruit set } \\
(\%)^{z}\end{array}$} & \multicolumn{2}{|c|}{ No. berries ${ }^{y}$} & \multirow{2}{*}{$\begin{array}{c}\text { Estimated } \\
\text { yield } \\
\left(t \cdot h a^{-1}\right)\end{array}$} & \multirow{2}{*}{$\begin{array}{l}\text { Anthocyanin } \\
(\mathrm{mg} / 100 \mathrm{~g})\end{array}$} \\
\hline & & Nonmarketable & Marketable & & \\
\hline \multicolumn{3}{|l|}{1989} & \multicolumn{3}{|c|}{ 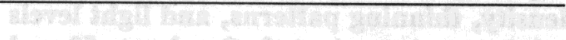 } \\
\hline None & 50 & 12 & $206 \mathrm{a}^{\mathrm{x}}$ & $17.5 \mathrm{a}$ & 78.7 \\
\hline Light & 57 & 15 & $195 \mathrm{a}$ & $16.0 \mathrm{ab}$ & 86.5 \\
\hline Moderate & 48 & 10 & $122 \mathrm{~b}$ & $10.4 \mathrm{bc}$ & 87.2 \\
\hline Heavy & 54 & 10 & $132 \mathrm{~b}$ & $9.7 \mathrm{c}$ & 87.0 \\
\hline Significance & NS & NS & * $*$ & $*$ & NS \\
\hline \multicolumn{6}{|l|}{$1990^{\circ}$} \\
\hline $\begin{array}{l}\text { None } \\
\text { Light }\end{array}$ & 29 a & 11 & $82 \mathrm{a}$ & $11.8 \mathrm{a}$ & $52.0 \mathrm{a}$ \\
\hline Moderate & $\begin{array}{l}41 \mathrm{ab} \\
45 \mathrm{~b}\end{array}$ & $\begin{array}{l}8 \\
4\end{array}$ & $\begin{array}{l}86 \mathrm{a} \\
70 \mathrm{ab}\end{array}$ & $\begin{aligned} 11.8 \mathrm{a} \\
9.4 \mathrm{ab}\end{aligned}$ & $68.3 \mathrm{~b}$ \\
\hline Heavy & $45 \mathrm{~b}$ & 5 & $48 \mathrm{~b}$ & $6.5 \mathrm{~b}$ & $71.0 \mathrm{~b}$ \\
\hline Significance & & NS & $* *$ & $* *$ & $*$ \\
\hline
\end{tabular}

${ }^{2}$ Fruit set $=$ no. berries divided by total no. flowers.

ySample area of $930 \mathrm{~cm}^{2}$.

xMean separation within seasons by the Waller test, $P<0.05$.

Ns,*,**,***Nonsignificant or significant at $P<0.05,0.01$, or 0.001 , respectively.

'McFarlin'. Also, the relative importance of fruit set as a yield component varied with year and site (Eaton and Kyte, 1978). In 1990, pruning severity did affect fruit set (Table 3 ). Although the unpruned vines had a lower fruit set than moderately or heavily pruned vines, this was apparently compensated for by higher numbers of $U_{F}$ and flowers, as unpruned vines tended to have a higher yield than moderately or heavily pruned vines (Table 3 ). In a study of seven cultivars, Eaton and MacPherson (1978) found that yield depended on $U_{F}$, but, in comparison, set was less important. The lower set in the unpruned plots was perhaps the result of denser canopies causing excessive dampness and shade and decreased accessibility of flowers by bees, preventing adequate pollination (Eck, 1990; Roberts and Struckmeyer, 1942). Eaton and Kyte (1978) found higher fruit set in less dense canopies. Shawa et al. (1981) suggested that in dense canopies of 'McFarlin', competition between vegetative growth (U,) and flower development may cause poor fruit set.

Berries from unpruned vines tended to have less anthocyanin in 1989, and in 1990, ber- ries from unpruned vines had significantly less anthocyanin than those from pruned vines (Table 3). Reduced anthocyanin is certainly a disadvantage in cranberry production as color is a major factor in quality. Thus, heavy shading in the unpruned plots, as indirectly evidenced by a higher sample plant fresh weight, a trend for higher number of runners, $U_{F}$ length, and $U_{N}$ length, leads to reduced fruit set and less fruit anthocyanin (Tables 2 and 3 ).

The total number of upright shoots ranged from 603 to 718 per $930 \mathrm{~cm}^{2}$. Thus, the upright density was much higher than the 200 to 300 uprights per equivalent unit area Roberts and Struckmeyer (1942) stated was an indication of optimum growth and maximum production. There was no difference in $\mathrm{U}_{\mathrm{T}}$ among pruning treatments in 1989 and 1990. However, the proportion of $U_{F}$ and $U_{N}$ was affected by pruning. The number of $U_{N}$ increased, whereas $\mathrm{U}_{\mathrm{F}}$ decreased, with pruning severity (Table 2). Thus, pruning stimulated $\mathrm{U}_{\mathrm{N}}$ growth. Percent $\mathrm{U}_{\mathrm{F}}\left(\mathrm{U}_{\mathrm{F}} / \mathrm{U}_{\mathrm{T}}\right)$ was highest in the unpruned plots in both years, but in $1989 \mathrm{U}_{\mathrm{F}}$ was similar for unpruned and lightly pruned plots (Table 2). Values ranged from
$18 \%$ in the heavily pruned plots to $35 \%$ in the unpruned plots in 1989. These proportions are similar to the $24 \%$ to $44 \% \mathrm{U}_{\mathrm{F}}$ found by Roberts and Struckmeyer (1942). However, percent $\mathrm{U}_{\mathrm{F}}$ dropped much lower the 2nd year in all treatments, indicating a detrimental effect of consecutive-year pruning on fruiting (Table 2).

Date of pruning had no effect on yield components of cranberry. The unpruned and lightly pruned plots had higher yields than the moderately and heavily pruned plots due to a higher number of fruiting uprights and berries. However, lack of pruning after 2 years led to reduced fruit anthocyanin. Chambers (1918) found a 10\% reduction in yield the year after pruning but a $45 \%$ increase in yield the 2 nd year after pruning, indicating that alternate-year pruning may be preferred. Strik et al. (1991) noted percent return bloom in fruiting uprights was as low as $31 \%$ in 'McFarlin'. Thus, most of the current season's crop would be from upright shoots that were vegetative $(\mathrm{U}$,$) the previous$ year. Under such conditions, alternate-year pruning may favor higher yield than pruning every year. Our research suggests that pruning lightly (removal of $<2 \mathrm{t}^{\circ} \mathrm{ha}^{-1}$ in a vigorous bed) in alternate years may lead to higher long-term yields without sacrificing fruit color.

\section{Literature Cited}

Chambers, F.S. 1918. Pruning experiments. Proc. 48th Annu. Meeting Amer. Cranberry Growers' Assn. p. 3-7.

Doehlert, CA. 1955. Pruning cranberries. Proc. 85th Annu. Meeting Amer. Cranberry Growers' Assn. p. 15-19.

Eaton, G. and T. Kyte. 1978. Yield component analysis in the cranberry. J. Amer. Soc. Hort. Sci. 103:578-583.

Eaton, G.W. and E.A. MacPherson. 1978. Morphological components of yield in cranberry. Hort. Res. 17:78-82.

Eck, P. 1990. The American cranberry. Rutgers Univ. Press, New Brunswick, N.J. p. 225-226.

Roberts, R.H. and B.E. Struckmeyer. 1942. Growth and fruiting of the cranberry. Proc. Amer. Sot. Hort. Sci. 40:373-379. 
Sapers, G.M. and D.L. Hargrave. 1987. Proportions of individual anthocyanins in fruits of cranberry cultivars. J. Amer. Soc. Hort. Sci. 112:10-104.

SAS Institute, Inc. 1987. SAS-STAT guide for personal computers, 6th ed. SAS Institute, Inc., Cary, N.C.

Shawa, A., G.W. Eaton, and P.A. Bowen. 1981. Cranberry yield components in Washington and British Columbia. J. Amer. Soc. Hort. Sci. 106:47ti77

Strik, B.C., T.R. Roper, C.J. DeMoranville, J.R. Davenport, and A.P. Poole. 1991. Cultivar and growing region influence return bloom in cranberry uprights. HortScience 26:1366-1367. 